Article

\title{
The Role of Economics and Democracy in Institutional Change for Sustainability
}

\section{Peter Söderbaum}

School of Business, Society and Engineering, Mälardalen University, 72123 Västerås, Sweden; E-Mail: peter.soderbaum@mdh.se

Received: 17 February 2014; in revised form: 23 April 2014 / Accepted: 26 April 2014 /

Published: 12 May 2014

\begin{abstract}
Institutional change for sustainable development does not happen by itself. Individuals and organizations function as actors to influence development processes. Reference is made to a "political economic person" (PEP) guided by her/his "ideological orientation" and "political economic organization" (PEO), guided by its "mission". Leaving present unsustainable trends behind is a matter of politics and ideology and even power positions, where democracy plays a crucial role. The perspectives of influential (and other) actors are essential in facilitating (or hindering) change. I will discuss ideas of the role of science in society, mainstream neoclassical economics in relation to institutional economics in the spirit of K. William Kapp and Gunnar Myrdal as well as neo-liberalism as ideology (where neoclassical economics has contributed to strengthen the legitimacy of neo-liberalism). Various aspects of inertia and flexibility in institutional change processes, such as path dependence, are discussed. Emphasis is on the role of economics and how a strengthened democracy can open the door for a degree of pluralism.
\end{abstract}

Keywords: political economics; ideological orientation; political economic person; political economic organization; neoclassical economics; institutional economics; democracy

\section{Introduction}

"Behavioral economics" has become a branch of mainstream economics as exemplified by the popularity of Daniel Kahneman's book Thinking Fast and Slow [1]. The studies by Kahneman and others are presented as something new and path-breaking. There may be some truth in such claims but Kahneman's work is part of a positivistic tradition with ambitious attempts to explain the behavior of 
individuals in specific situations by testing hypotheses. Attempts are made to make general statements of an objective and value-neutral kind about human behavior in such situations.

In relation to sustainable development and sustainability I will here argue that there are other possible and more important contributions to economics by social and behavioral sciences, such as psychology, sociology, social psychology and educational science. Political science, sometimes referred to as the science of governance, and management science also have something to offer. What is needed is a conceptual framework that is useful in understanding the behavior of individuals and organizations as actors.

Some economists have at an early stage pointed in the direction of such a conceptual framework. I am thinking of Kenneth E. Boulding and his books Beyond Economics [2] and Economics as a Science [3] and Herbert Simon's Administrative Behavior which appeared as early as 1947 [4]. Simon and his followers pointed to "bounded rationality" and "satisficing behavior" as key concepts. In complex decision situations "perfect information" does not exist. Even in management science there has been an early interest to learn from social psychology, for example in areas such as marketing and consumer behavior [5,6]. These authors used concepts such as role, relationship, motive, perception, cognition, identity and referred to learning theory as a way of understanding the establishment of habits and other changes in human behavior. Human beings in specific power and resource positions are related to contexts that are social, cultural, ecological and physical, man-made.

So, the behavioral (or socio-psychological) turn in economics is for some of us not so new. In this chapter I will as much point to a "political turn" in economics. Individuals and organizations will be understood as political actors in a democratic society. Democratizing economics [7] and strengthening democracy generally is suggested as important steps toward a more sustainable society. In the present situation pluralism in economics is deeply needed.

\section{A "Political Turn" in Economics}

Classical economists referred to their field of study as "political economics". This terminology was abandoned when a more technocratic and mechanistic view of the subject became dominant about 1870. From then on attempts were made to reduce or eliminate the political element in economics. Neoclassical economists referred to "economics" rather than "political economics", the idea being to develop a science much like physics and other natural sciences.

It is here argued that it was a mistake to abandon the term "political economics". Mainstream neoclassical economics is specific in value, ideological or political terms and the same is true of specific versions of institutional economics, feminist economics, ecological economics or any other school of thought in economics. Any habit to exclusively use "political economics" when referring to Marxist economics is here rejected.

The value, ideological, or political element is present for the scholar as researcher and teacher as well as for our view of other actors in the economy or society. Among economists, Gunnar Myrdal focused on our roles as scholars and argued as follows: 
"Valuations are always with us. Disinterested research there has never been and can never be. Prior to answers there must be questions. There can be no view except from a viewpoint. In the questions raised and the viewpoint chosen, valuations are implied.

Our valuations determine our approaches to a problem, the definition of our concepts, the choice of models, the selection of observations, the presentation of our conclusions - in fact the whole pursuit of a study from beginning to end." [8]

Rather than referring to "values" and "valuations" as in the citation, I will use the terms "ideology" and "ideological orientation" where ideology stands for "means-ends relationship". An individual is assumed to be an actor and political-economic person (PEP) guided by his/her ideological orientation. "Ideological orientation" refers to an ethical and moral compass including relationships with elements other than human beings [9]. It is about where you are (present position), where you want to go (future positions) and how to get there (strategy) [10,11]. An organization is similarly assumed to be a political-economic organization (PEO) and actor guided by its ideological orientation or rather "mission". The two concepts "ideological orientation" and "mission" are largely synonymous but ideological orientation tends to be used mainly for individuals and mission for organizations such as firms. Both concepts suggest an opening to include broader considerations in addition to more narrow objectives.

The word "ideology" often refers to political parties and other collective entities. However, if politicians present their ideological orientations in the attempt to become elected then the citizens may refer to world-views and visions that can be understood in similar terms and can be assumed to be useful when voting for specific political parties and for other decision-making purposes. Decision-making is understood as a "matching" process between an actor's ideological orientation (mission) and expected impacts for each alternative of choice considered. Some alternatives match an ideological orientation better than others or are more "appropriate". Among scholars in the field of management, James March pointed at an early stage [12] to "appropriateness" as a criterion of selection. It may be recalled that also Friedrich Schumacher among scholars concerned about sustainability issues referred to "appropriate technology" in his book Small is beautiful [13]. "Pattern recognition" is another term that suggests that an actor's ideological orientation as a (visual and other) pattern is matched against the pattern of impacts connected with each alternative considered.

Ideological orientation (mission) can be expressed in qualitative, quantitative or visual terms and is not limited to a mathematical objective function to be maximized. While being characterized by some stability, the ideological orientation (mission) is also subject to reorientation and adapted to changing roles, relationships and contexts. The ideological orientation of an individual and mission of an organization is furthermore fragmented and uncertain. It is often tentative rather than fixed and differs from situations of complete information assumed in neoclassical theory.

PEP- and PEO-assumptions still represent simplifications of individuals and organizations but claim to be closer to the "real world" than neoclassical assumptions. The idea is to open the door for a more constructive idea of individuals and organizations in relation to a policy and politics for sustainable development. 


\section{Sustainable Development—What do We Mean?}

In Western societies, and perhaps in the world generally, we have experienced a hegemony of actors who share rather simplistic ideas about progress in society and in business. Economic growth in GDP-terms and profits in business has been and continues to be regarded as the main objectives with limited consideration of other objectives. Performance can certainly be quantified in monetary terms but this habit in many establishment circles is here questioned as "monetary reductionism". In response institutions such as Environmental Management Systems (EMS) and Global Reporting Initiative (GRI) have emerged.

The concept of sustainable development with one of its origin in Our Common Future, the so called Brundtland report [14] has played a role in these changes in ideological orientation and institutional change processes. Actually, the title of the Brundtland report suggests that society and the economy are not only based on self-interest but that we also have essential interests in common. Sustainable development as a concept has the potential to further influence development patterns. Actually, it opens the door for consideration of different ethical principles as well as ideas of progress in society.

However, sustainable development does not mean one thing for all actors. Rather it is interpreted in different ways and a kind of power game is taking place between proponents of various interpretations. I have elsewhere made a distinction between three admittedly simplified interpretations $[15,16]$ :

- Business as usual (BAU) in the sense of focus on monetary profits and economic growth (or perhaps sustained monetary profits and sustained growth);

- Modernization in the sense that the existence of serious social and environmental problems is recognized and that there is a willingness to modify the present political economic system to deal constructively with the problems. It is assumed or believed that modification is enough;

- Radical change where the judgment is made that one also has to consider radical (institutional) change in the present political economic system.

EMS and GRI exemplify changes in institutional arrangements at the level of organizations that belong to the "modernization" category. The present political economic system is modified, not radically changed. Social and environmental performance is made more visible while the introduction of these systems is made on a voluntary basis.

Consideration of "radical" institutional change is not discussed so much but rather a subject that is avoided. However, it is possible to think of organizations where the profit motive is down-played or of a world trade organization that differs from the present WTO. The constitution or legal context of joint stock companies dictates that the monetary dimension, and performance in relation to shareholders, plays a central role. However, the challenges in relation to sustainable development are primarily a matter of non-monetary performance of a social and environmental kind. It may therefore be argued that joint stock companies are miss-constructed in relation to present needs. The present World Trade Organization (WTO) is built upon simplistic economic theory implying that international trade is always good for the countries involved. Possibilities of market failure and the existence of conflicting interests in each of the trading countries is forgotten or assumed away. Non-monetary and ethical considerations are largely absent. 
I am unable to present simple solutions to these complex issues but the important thing in the present situation is to raise these issues and initiate a dialogue. Sustainable development stands for non-degradation of ecosystems and the natural resource base in the home country and at a global level. A philosophy of cautiousness also belongs to these principles of sustainable development.

\section{Ideological Orientation is Something to be Investigated Rather than Assumed as Given}

Getting closer to sustainable development is not only a matter of public policy but also of the ideological orientation or mission of actors. An actor's ideological orientation may change more or less with changing roles and contexts over time and actors belonging to one category (e.g., individuals) can be expected to differ with respect to ideological orientation. Each actor is responsible and accountable for her ideological orientation (mission) and the actions that follow. As scholars belonging to universities we should ourselves enter into a dialogue with other actors in society, making arguments visible. Rather than assuming that all individuals (firms) have a specific ideological orientation (mission) and behave in a specific manner we take an interest in differences between individuals (firms) and how each actor understands sustainable development and the motives behind.

This points in the direction of case studies of specific sustainability issues with individuals and organizations as actors. How do these actors interpret "sustainable development" and how does such interpretation influence their actual behavior and actions? How do they perceive their context and their own power position and options to behave in ways more compatible with sustainable development? Approaches to science focusing on the subjectivity of actors, such as hermeneutics, narrative theory and analysis $[17,18]$ then become relevant.

\section{Redefining Economics as Multidimensional Management of Resources in a Democratic Society}

At any given moment in time we are locked into a specific political economic system in broad terms and in details. Each actor is related to a context that is characterized by different kinds of inertia and path dependence. The actor herself is more or less committed to an ideological orientation and ways of dealing with her immediate and more distant context. Inertia is a phenomenon relevant in various kinds of dimensions $[19,20]$. At the same time some options are normally available for single actors and groups of actors. Few of us experience a complete lock-in situation.

This is where the existence of democracy comes to the fore. Democracy and institutional change are closely connected. Moreover, there is no society or sector of an economy where democracy cannot be improved or strengthened. Inertia and path dependency can be a matter of mechanistic forces but also a matter of social power games and social propaganda and protectionism. Not all actors in media or representatives of transnational business are ready to discuss radical institutional change.

It should be observed that "democracy" is here understood in broader terms than decision-making by majority rule and referendum. Democracy is about observing human rights and the existence of a respected legal system. Individuals and organizations are responsible and accountable actors (as PEPs and PEOs respectively). Democracy is furthermore opposed to political dictatorship and also to technocracy, a dictatorship by experts. In a democracy a degree of pluralism with respect to opinions and ideological orientations prevail. Tensions between advocates of different ideological orientations, 
freedom of speech and opportunities for public debate are regarded as normal and constructive for the progress of society.

My concern here is mainly with the role of universities and more precisely university departments of economics in relation to institutional change. Mainstream neoclassical economics is specific in scientific but also in ideological terms. Ideologically, mainstream neoclassical theory can be described as the ideology behind present market capitalism. Unfortunately there is a monopoly position for neoclassical theory at departments of economics, a situation which is not compatible with democracy. This applies in particular for introductory economics textbooks and courses. Only pluralism with respect to theoretical (and thereby ideological) perspectives is compatible with democracy.

I have elsewhere [21] suggested that economics is defined as "multidimensional management of resources in a democratic society". This has the potential of changing education and research at university departments of economics considerably and would strengthen democracy. Mainstream economists appear to look upon democracy as something that belongs to other disciplines. Introductory textbooks in economics hardly mention democracy [22] and tend to look upon their subject as a matter of expertness and technocracy.

The challenge of sustainable development is largely of a non-monetary kind while neoclassical economics with its Cost-Benefit Analysis (CBA) analysis focuses on the monetary dimension. It is assumed that all kinds of impacts can be traded against each other in monetary terms. The alternative here is to keep monetary and (various kinds of) non-monetary impacts separate and accept some degree of complexity. Respecting democracy furthermore means that the existence of more than one ideological orientation among decision-makers, professionals, stakeholders and other actors is recognized. Ideas about economics, efficiency and rationality then become a matter of your ideological orientation. An analysis more open in conceptual and ideological terms represents a move away from technocracy to a strengthened democracy.

\section{The Role of Science and Social Movements for Institutional Change}

Radical change in science is normally thought of as paradigm shifts. Following a positivist tradition scientists are seeking truth and nothing else. It is believed that changes in values and ideological orientation occur outside universities and are essentially separate or separable from research and education. Social movements in the larger society need not bother us as scholars.

Our present political economics perspective differs from the positivist tradition. It is argued here that each social science paradigm is specific also in ideological terms and even that each one of us as scholars is guided by an ideological orientation. As scholars we are influenced by what happens in the larger society in terms of social movements and we can even actively participate in and influence such movements. Among more visible social movements, environmental organizations such as Greenpeace and Occupy World Street [23,24] can be mentioned but there are obviously many more or less visible trends of value and policy formation.

There are social movements and related institutional change also within the academia. This may be manifested in new associations with their own conferences and journals. As an example the International Society for Ecological Economics (ISEE) was formed in part as a scientific and ideological criticism of neoclassical economics and its branch neoclassical environmental 
economics $[25,26]$. Kenneth Boulding and Herman Daly criticized the economic growth ideology and the ethical assumptions made in mainstream economic theory. Ecological economists have tried to socially construct an alternative conceptual framework, i.e., concepts that differ from those of neoclassical microeconomics.

A distinction can be made between the mainstream perspective and alternative perspectives (Table 1). Present institutional arrangements, such as the joint stock company and the World Trade Organization (WTO) largely follow from the dominance of positivism as a theory of science, the dominance of neoclassical theory in economics research and education and the dominance of neo-liberalism as ideology with its focus on markets and economic growth. While not being the only explanatory factors, it is argued that the indicated perspectives within science play a role in making specific institutional arrangements legitimate. This suggests that also scientists should open the door for a dialogue at the level of perspectives. Rather than thinking in terms of paradigm-shift we should accept situations of "paradigm co-existence". While each scholar may have her/his preferences, pluralism with respect to perspectives becomes a natural strategy. Having admitted that values and ideology are involved, monopoly for one perspective becomes controversial in a democratic society.

Table 1. Mainstream and alternative perspectives and the institutional arrangements that may follow, i.e., are made legitimate.

\begin{tabular}{l|l|l}
\hline Theory of science & Mainstream perspectives & \multicolumn{1}{c}{ Alternative perspectives } \\
\hline Economics paradigm & Positivism & $\begin{array}{l}\text { Hermeneutics, narrative analysis, } \\
\text { social constructivism }\end{array}$ \\
\hline Ideological orientation & $\begin{array}{l}\text { Neo-liberalism, } \\
\text { economic growth }\end{array}$ & $\begin{array}{l}\text { Some version of institutional or } \\
\text { ecological economics }\end{array}$ \\
\hline Institutional arrangements & $\begin{array}{l}\text { Examples: Joint stock } \\
\text { company, World Trade } \\
\text { radical change in political economic system }\end{array}$ \\
\hline
\end{tabular}

Thomas Kuhn's original study of paradigm change referred primarily to natural sciences [27]. Our interest here refers primarily to social sciences where ethics and ideology plays a more important role. It may be added that while respecting more than one theoretical perspective, the paradigm-shift idea may still be relevant but then in terms of a "shift in dominant paradigm". Neoclassical theory may at some stage lose adherents while still being among the alternative theoretical perspectives considered.

Accepting the subjective and political aspect of economics and the theory of science approaches listed in the right-hand column of Table 1 means that the criteria of good science change a bit. Some criteria connected with positivism are still valid but compatibility with democracy is added as a new set of criteria. Analysis has to be many-sided, reflecting the different ideological orientations of stakeholders and other actors concerned. As an example, neoclassical Cost-Benefit Analysis (CBA) builds on one single ideological orientation-ideas of "correct" prices - which is not compatible with democracy. Only in the rare case that all stakeholders and concerned actors agree about the CBA idea of correct prices can this particular method be used. In relation to environmental issues and sustainable 
development there are many ideas of reasonable prices for irreversible or other impacts as observed by Ezra Mishan among others [28].

\section{Inertia and Institutional Change}

At a given point in time each actor in a society is faced with specific institutional arrangements as part of her context. Relevant institutions may be local, national and even global as in the WTO case mentioned above. The existence of "path dependence" [29] suggests that single institutions and larger systems of interconnected institutions are not easily changed. Such phenomena of inertia can be discussed under various labels. Reference can be made to "lock-in effects", "commitments", "irreversibility" in various dimensions.

While there is path-dependence it is also true that existing institutions can be modified gradually and that new institutions may emerge. There may be minor institutional change or more radical reframing of institutions. New institutions may reduce the role of previously existing ones or replace them completely.

Our present interest is institutional change for sustainable development. While some steps have been taken, a lot remains. It can even be argued that some institutions that represent barriers to sustainable development have been further strengthened in the recent past. At issue is now how one can increase the relative role of (minor or major) institutional change that will contribute positively to sustainable development. As already indicated, dialogue at the level of perspectives (theory of science, paradigm in economics and ideological orientation) is of crucial importance. Today, this kind of dialogue is largely avoided. Too many establishment actors (and other actors) appear to perceive the present political-economic system as the only possibility. "There is no alternative" in the words of Margaret Thatcher.

However, a public debate is going on and some institutional change takes place all the time. Politics exist at the local, national, regional (for example EU) levels but institutional change need not exclusively be a matter of national or European Union reforms. Institutional change may as well be initiated by individuals and organizations at the local level. Those who have (more or less) internalized the ideological orientation of sustainable development can focus on the social and environmental impacts of their own practices suggesting and implementing creative solutions. If other actors imitate their practices, certification systems can at some stage be organized and emerge as new institutions. This is a way of understanding how Environmental Management Systems, such as ISO 14001 and the Global Reporting Initiative came about. While more is needed for a truly sustainable development, minor steps in the right direction should also be acknowledged and encouraged.

\section{Conclusions}

National and regional governments, such as the European Union can prepare and implement reforms that are instrumental to a more sustainable development. However, individuals and organizations as political actors can also contribute. Actually, what happens at the level of nations and the EU is also a matter of how individuals understand the world and the actions that follow.

Citizens, professionals and politicians all refer to their specific ideas of economics. Some connect economics with money and the monetary or financial aspect of behavior and policies. Neoclassical 
economics tends to legitimate such simplifications when pointing to the role of prices and other incentives. There is certainly some relevance in such views and arguments. However, neoclassical economics has been in a monopoly position at a time when environmental and natural resource problems have been aggravated. A first step in the present situation is to abandon the neoclassical monopoly in university education in favor of a pluralistic strategy where alternative perspectives in economics are encouraged and institutionalized.

Gunnar Myrdal and also K. William Kapp [30] pointed to the role of values in economics research and education. I have rather emphasized the terms of "ideological orientation" and "mission". We should all admit that ideology is involved in development processes at various levels. Neoclassical economists tend to respect scholars in natural sciences and those active in physics in particular. I want therefore to refer to Murray Gell-Mann, Nobel Laureate in Physics, who has identified "ideological transition" as one of seven necessary transitions for sustainable development [31]. I agree with him that a debate about ideological orientation and mission plays a key role in our attempts to get closer to a sustainable development.

A debate about sustainable development is going on at many places but it is also true that many are those who use their power positions to advocate traditional ideas of development in terms of GDP-growth and business profits. Each actor certainly has the right to participate in debate but discriminatory tendencies implying protection of presently unsustainable trends need to be questioned. This brings us back to our political turn in economics and the importance of a strengthened democracy in each part of society, nationally and globally. As actors we should all consider our responsibilities and accountability.

\section{Conflicts of Interest}

The author declares no conflict of interest.

\section{References and Notes}

1. Kahneman, D. Thinking Fast and Slow; Penguin Books: London, UK, 2011.

2. Boulding, K.E. Beyond Economics: Essays on Society, Religion, and Ethics; The University of Michigan Press: Ann Arbor, MI, USA, 1968.

3. Boulding, K.E. Economics as a Science; McGraw-Hill: New York, NY, USA, 1970.

4. Simon, H.A. Administrative Behavior; Macmillan: New York, NY, USA, 1947.

5. Howard, J.A. Marketing Management: Analysis and Planning; Irwing: Homewood, IL, USA, 1963.

6. Engel, J.E.; Kollat, D.T.; Blackwell, R.D. Consumer Behavior; Holt, Rinehart and Winston: New York, NY, USA, 1968.

7. Söderbaum P.; Brown, J. Democratizing economics_-Pluralism as a path toward sustainability. Ann. N.Y. Acad. Sci. 2010, 1185, 179-195.

8. Myrdal G. Institutional Economics. J. Econ. Issues 1978, 12, 771-783.

9. Kenneth Boulding wrote a chapter "Economics as a Moral Science" in his book from 1970.

10. North, D.C. Institutions, Institutional Change and Economic Performance; Cambridge University Press: Cambridge, UK, 1990. 
11. Douglass North repeatedly refers to ideology in his discussion of institutional change. For him "ideology" stands for "the subjective perceptions (models, theories) all persons possess to explain the world around them. Whether at the micro level of individual relationships or at the macro level of organized ideologies providing integrated explanations of the past and the present, such as communism or religions, the theories individuals construct are colored by normative views of how the world should be organized" ([10] (p. 23), italics in original).

12. March, J. A Primer on Decision Making: How Decisions Happen; The Free Press: New York, NY, USA, 1994.

13. Schumacher, F. Small is Beautiful: Economics as if People Mattered; Harper \& Row: New York, NY, USA, 1973.

14. World Commission on Environment and Development. Our Common Future (the Brundtland Report); Oxford University Press: Oxford, UK, 1987.

15. Söderbaum, P. Ecological Economics: A Political Economics Approach to Environment and Development; Earthscan: London, UK, 2000.

16. Söderbaum, P. Understanding Sustainability Economics. Towards Pluralism in Economics; Earthscan: London, UK, 2008.

17. Ricoeur, P. Hermeneutics and the Human Sciences; Cambridge University Press: Cambridge, UK, 1981.

18. Porter, A.H. The Cambridge Introduction to Narrative; Cambridge University Press: Cambridge, UK, 2002.

19. Söderbaum, P. Positionsanalys vid beslutsfattande och planering. Ekonomisk analys på tvärvetenskaplig grund (Positional Analysis for Decision-making and Planning. Economic Analysis on Interdisciplinary Basis); Esselte Studium: Stockholm, Sweden, 1973. (In Swedish)

20. In this early study the following dimensions were listed in addition to the monetary dimension so often emphasized in economics ([19] (pp. 64-66)): psychological dimension, dimensions related to information and knowledge, social dimensions, ethical dimensions, dimensions related to law, aesthetic dimensions, physiological dimensions, biological dimensions, chemical dimensions, ecological dimensions, physical-technical dimensions, space dimensions and historical dimensions.

21. Söderbaum, P. From Technocracy to Democracy: Are Ecological Economists Part of a Social Movement for Sustainable Development? In Proceedings of the ESEE (European Society for Ecological Economics) Conference, Lille, France, 18-21 June 2013.

22. This can be exemplified with Gregory Mankiw's Principles of Economics (2009) South-Western, Cengage Learning [cengage.co.uk] where "democracy" is not part of the subject index. The reader is invited to make her or his own observations.

23. Jackson, R. Occupy World Street: A Global Roadmap for Radical Economic and Political Reform; Chelsea Green Publishing Company: Hartford, VT, USA, 2012.

24. Graeber, D. The Democracy Project: A History, a Crisis, a Movement; Allen Lane: London, UK, 2013.

25. Røpke, I. The early history of modern ecological economics. Ecol. Econ. 2004, 50, $293-314$.

26. Røpke, I. Trends in the development of ecological economics from the late 1980s to the early 2000s. Ecol. Econ. 2005, 55, 262-290. 
27. Kuhn, T. The Structure of Scientific Revolutions, 2nd ed.; University of Chicago Press: Chicago, IL, USA, 1970.

28. Mishan E. How valid are economic valuations of allocative changes? J. Econ. Issues 1980, 14, $141-161$.

29. North, D.C. Understanding the Process of Economic Change; Princeton University Press: Princeton, NJ, USA, 2005.

30. Kapp, K.W. The Nature and Significance of Institutional Economics. Kyklos 1976, 29, 209-232.

31. Gell-Mann, M. The Quark and the Jaguar: Adventures in the Simple and the Complex; Abacus: London, UK, 1995. The other transitions in Gell-Mann's list are the demographic transition, the technological transition, the economic transition, the social transition, the institutional transition and the information transition.

(C) 2014 by the author; licensee MDPI, Basel, Switzerland. This article is an open access article distributed under the terms and conditions of the Creative Commons Attribution license (http://creativecommons.org/licenses/by/3.0/). 